Article

\title{
Locating Cities and Their Governments in Multi-Level Sustainability Governance
}

\author{
Thomas Hickmann \\ Copernicus Institute of Sustainable Development, Utrecht University, 3584 CB Utrecht, The Netherlands; \\ E-Mail: t.hickmann@uu.nl
}

Submitted: 31 August 2020 | Accepted: 7 February 2021 | Published: 26 February 2021

\begin{abstract}
Cities and their governments are increasingly recognized as important actors in global sustainability governance. With the adoption of the 2030 Agenda for Sustainable Development, their role in the global endeavor to foster sustainability has once again been put in the spotlight. Several scholars have highlighted pioneering local strategies and policies to implement the Sustainable Development Goals and render urban areas more sustainable. However, the question of how such urban sustainability actions are embedded in complex interactions between public and private actors operating at different levels has not been studied in enough detail. Building upon a multi-level governance approach, this article explores the entanglement and interconnectedness of cities and local governments with actors and institutions at various levels and scales to better capture the potential and limitations of urban policymaking contributing to global sustainability. The article finds that on the one hand cities and their governments are well positioned to engage other actors into a policy dialogue. On the other hand, local authorities face considerable budgetary and institutional capacity constraints, and they heavily rely on support from actors at other governmental levels and societal scales to carry out effective sustainability actions in urban areas.
\end{abstract}

\section{Keywords}

2030 Agenda; cities; local governments; multi-level governance; Sustainable Development Goals

\section{Issue}

This article is part of the issue "The 2030 Agenda for Sustainable Development: Transformative Change through Sustainable Development Goals?" edited by Thomas Hickmann (University of Utrecht, The Netherlands), Markus Lederer (Technical University of Darmstadt, Germany), Jens Marquardt (Technical University of Darmstadt, Germany), Sandra Schwindenhammer (Justus Liebig University Giessen, Germany) and Sabine Weiland (Catholic University of Lille, France).

(C) 2021 by the author; licensee Cogitatio (Lisbon, Portugal). This article is licensed under a Creative Commons Attribution 4.0 International License (CC BY).

\section{Introduction}

Over the past few years, numerous scholars have pointed to the growing importance of cities and their governments in global policymaking (e.g., Amen, Toly, McCarney, \& Segbers, 2011; Curtis, 2014). Cities are described as spaces for creative responses to global problems, as sites of new policy cultures with less hierarchical structures, and as important hubs for innovation in the digital age. Mayors and other representatives of local governments moreover increasingly take part in international conferences and form networks and alliances to cooperate with each other and advocate for their common interests (Bäckstrand, Kuyper, Linnér, \& Lövbrand,
2017). These developments are not entirely new but seem to have lately gained another quality and are especially prevalent in global sustainability governance.

The 2030 Agenda for Sustainable Development (2030 Agenda) adopted by United Nations General Assembly in 2015 highlights the significance of the local level to attain sustainable development worldwide (United Nations, 2015). The 2030 Agenda encompasses 17 Sustainable Development Goals (SDGs) covering the economic, social, and environmental dimensions of sustainable development. SDG 11 on inclusive, safe, resilient, and sustainable settlements is especially dedicated to the local level and several other goals are closely related to cities and municipalities, such as (inter alia) 
SDG 6 on clean water and sanitation, SDG 9 on industry, innovation, and infrastructure, SDG 10 on reduced inequalities, and SDG 12 on responsible consumption and production. This article focuses on the environmental dimension of the 2030 Agenda and explores the role of cities and their governments to achieving these goals.

In the literature, there are many studies about frontrunner cities like Barcelona, Copenhagen, Freiburg, Portland, Sidney, Utrecht, or Yokohama. Numerous authors have shown that the governments of these cities carry out pioneering sustainability measures and adopt nature-based solutions in urban areas (e.g., Dorst, van der Jagt, Raven, \& Runhaar, 2019; Simon, 2016). In the C40 Cities Climate Leadership Group, the world's most populous cities share their knowledge on best practices to take climate actions and position themselves as global leaders for attaining sustainability (Davidson, Coenen, \& Gleeson, 2019; Román, 2010). Likewise, smaller cities conduct local sustainability projects and join forces in global coalitions, such as the Global Resilient Cities Network or ICLEI-Local Governments for Sustainability, in regional clusters, such as Energy Cities or the ASEAN Smart City Network, as well as in numerous national city associations.

Despite this rise in local sustainability actions, we have to be careful to not overestimate the abilities and capacities of cities and their governments to foster sustainability worldwide. The material resources of mayors and local administrations vary considerably, but they are generally limited and dependent on support from actors at other governmental levels and societal scales. To conduct sustainability projects on the ground, cities and local governments rely on regional and national governments, international funding schemes, civil society engagement, and private corporations that all operate in the multi-level governance system. This is sometimes neglected in the debate about the opportunities of cities and their governments to address sustainability issues in urban areas. The present article therefore explores the embeddedness of cities and their governments in multilevel sustainability governance.

In particular, the article analyzes their entanglement and interconnectedness in multi-level governance dynamics in three dimensions. In a first dimension, the article examines the vertical interlinkages of cities with regional and national governments and their involvement in international conferences led by the United Nations on climate change and sustainable development. In a second dimension, the article scrutinizes the horizontal interplay of municipalities with public and private actors in their jurisdictions. In a third dimension, the article studies the transnational interplay of cities in networks and alliances. The article's principal aim is to put forward a conceptual argument that the abilities and capacities of cities and their governments to contribute to global sustainability need to be seen in the context of the overall multi-level governance system. To develop this argument, the present article focuses on studies from the field of climate and sustainability politics and governance and draws on some illustrative examples from this burgeoning scholarship.

The article proceeds in the following way. In Section 2, 1 depict the growing recognition of cities in global sustainability governance and contextualize the article within the broader body of literature on this topic. In Section 3, I sketch a multi-level governance perspective for the location of cities and their governments in global sustainability governance. In Section 4, I provide a number of empirical examples to underscore the entanglement and interconnectedness of cities and their governments with other actors in the sustainability domain. Finally, I draw some general conclusions on the role and function of cities and local governments in the global endeavor to achieve sustainability and point to a promising research avenue.

\section{The Growing Recognition of Cities in Global Sustainability Governance}

This article starts off from the notion that cities and their governments are to a growing extent recognized as key actors in global sustainability governance. And indeed, today most people live in urban areas and a high proportion resides in mega-cities where the bulk of global greenhouse gases is emitted, where large shares of global energy and fresh water are consumed, and where big amounts of waste materials are produced (e.g., Shmelev, 2017). According to the United Nations Human Settlements Programme, about 55\% of the approximately 7,5 billion people in the world live in cities (UN Habitat, 2016). Projections by UNDESA state that until 2050 more than two thirds of the world's population will live in urban agglomerations, while in particular large cities with more than five million inhabitants are expected to rise rapidly in the next decades (UNDESA, 2019).

Scholarship on the role of the local level in global policymaking has evolved considerably over the past years. Authors have pointed to global trends of decentralized decision-making and referred to the changing relationship between local and national governments (e.g., Brenner, 1998; Sassen, 1994; Scott, 2001). Studies in the field of environmental politics have also drawn considerable attention to the role of cities and local governments in the global responses to different sustainability problems, first and foremost to the issue of climate change (Betsill, 2001; Bulkeley \& Betsill, 2005; Kousky \& Schneider, 2003). All these studies have enhanced our understanding of the significance of the local level in global sustainability governance and many other policy domains.

Several authors have lately also argued that cities and their governments are better suited and more agile to address sustainability issues than central governments since they are not caught up in slow and tedious international bargaining processes (Acuto, 2013; 
Rosenzweig, Solecki, Hammer, \& Mehrotra, 2010). Local authorities are confronted with similar sustainability problems and challenges like air pollution, heat waves, complex supply chains, recycling systems, and basic universal health. There are, however, also strong differences: Some cities, especially mega towns in the global South, are rapidly growing - putting an additional stress on them, while other municipalities in structurally disadvantaged regions suffer from shrinking populations and a brain drain of high-skilled professionals (Hansen, Ban, \& Huggins, 2003; Nagendra, Bai, Brondizio, \& Lwasa, 2018). Local governments have hence to deal with numerous dimensions of sustainability transformations (Vardoulakis \& Kinney, 2019).

A number of cities have adopted targeted strategies and pursue their own policies to render their urban areas more sustainable (Sodiq et al., 2019). These initiatives have been framed as urban sustainability experiments (Peng, Wei, \& Bai, 2019; Sengers, Berkhout, Wieczorek, \& Raven, 2016). Local governments launch such innovations for different reasons (Fuhr, Hickmann, \& Kern, 2018): Cities like Beijing, Delhi or Jakarta face high problem pressure and cope, for instance, with periods of intense smog and air pollution; other cities allow for elements of direct democracy and participation leading to policy innovations for sustainability; some cities have more political leeway and resources to implement local sustainability measures; urban areas like San Francisco with a green industry have become centers for sustainability products; and some mayors have demonstrated political leadership by adopting effective urban sustainability strategies (see also Gordon, 2018).

The pioneering initiatives of some cities to promote sustainability at the local level have in the recent literature been contrasted with the lack of ambition of national governments to fight global environmental problems like climate change, biodiversity loss, and land degradation (Rosenzweig et al., 2010). This has led to frustration with international negotiations on transboundary sustainability issues. Such disappointment has been spurred by the experience of the failure of the climate summit in Copenhagen in 2009 when the heads of state and government of the major powers could not agree on a new climate treaty to replace the Kyoto Protocol (Hoffmann, 2011). As a result, several scholars pointed to alternatives to the tenacious intergovernmental attempts to establish a regulatory framework for dealing with climate change and many of them devoted particular attention to cities and their networks (Chan et al., 2015; Gordon \& Acuto, 2015; Romero-Lankao et al., 2018).

This evolving scholarship has raised high expectations in the role and function of cities and local governments in the global response to climate change and the global endeavor to foster sustainable development (Chan et al., 2019). Benjamin Barber's books If Mayors Ruled the World: Dysfunctional Nations, Rising Cities (2013) and Cool Cities: Urban Sovereignty and the Fix for Global Warming (2017) are prominent examples of such great hopes. That research line has raised public awareness of local sustainability actions. Yet, some of these studies have an overtly optimistic tone regarding the impact of local sustainability initiatives on global developments and tend to overestimate the capacities of cities and their governments to cope with sustainability issues independently from actors at other levels and scales.

While there is good reason to regard cities as important actors in global sustainability governance, this article offers a more nuanced perception of the role of cities and their governments within this realm. To this end, it builds upon a multi-level governance approach and highlights the embeddedness of cities and local governments in urban sustainability policymaking to better capture their potential and limitations for contributing to global sustainability.

\section{A Multi-Level Governance Perspective on the Role of Cities and Their Governments in the Sustainability Domain}

The term 'multi-level governance' is today widely used in the literature to conceptualize the various linkages between different actors and institutions in a given policy domain or in the whole global governance system. Originally introduced and used by scholars dealing with the European Union to account for the complex relations between local, national, and European levels of decision-making (Hooghe \& Marks, 2001; Marks, 1993), authors dealing with environmental politics have subsequently adopted the concept and applied it on national and global climate governance (e.g., Gupta, 2007; Kern \& Alber, 2008; Selin \& VanDeveer, 2012; Weibust \& Meadowcroft, 2014).

Following Liesbet Hooghe and Gary Marks (2003), two types of multi-level governance perspectives can be distinguished. A first Type I multi-level governance perspective focuses on public authorities and their interactions across governmental levels (from the local to the global). A second Type II multi-level governance perspective does not exclusively look at vertical interactions between governmental actors at different levels, but also takes their horizontal relationships with private actors, academic institutions, and civil society groups as well as their transnational interlinkages into account. This latter perspective provides a suitable lens for analyzing the role of cities and local governments in global climate and sustainability policymaking (Bulkeley \& Betsill, 2005, 2013).

While the multi-level governance perspective is a useful approach for exploring interlinkages between actors across levels and scales, the concept does not account for the often-huge differences between actors and institutions in terms of power constellations, legal status, or political leeway (Bulkeley \& Betsill, 2013). With regard to the topic dealt with in this article, it can be argued that the multi-governance perspective 
cannot adequately capture the variances between individual cities across the world and their positions to take urban sustainability actions (Homsy, 2018). To delve deeper into the particularities of different cities and their concrete interlinkages to other actors in the global responses to sustainability problems, the multi-level governance perspective needs to be complemented with other approaches. Thus, the effort of this article to locate cities in multi-level sustainability governance provides some groundwork for future studies that strive to investigate power asymmetries, diverging interests, and norm conflicts between local authorities and actors at other levels and scales.

As noted earlier, the 2030 Agenda is supposed to promote a global sustainability transformation (United Nations, 2015). This global endeavor requires a multiactor effort in which many transformational developments take place in urban areas (Romero-Lankao et al., 2018), while the various sustainability projects and activities carried out in cities are embedded in the larger governance system. The great advantage of the multilevel governance perspective is that it offers insights into the entanglement and interconnectedness of cities and their governments within the wide web of actors dealing with sustainability. The multi-level perspective shows that cities and local governments are not isolated actors; and it emphasizes that their ability to undertake sustainability projects in their jurisdictions and pursue policies is enabled or constrained by their surrounding landscape of actors and institutions. Building upon a Type II multi-level governance approach (Bache, Bartle, \& Flinders, 2016), this article focuses on three dimensions of this embeddedness.

First, the article looks at the vertical integration of cities and local governments within national systems and at their involvement in international conferences. Second, the article looks at horizontal interactions of cities and local governments with civil society groups, educational and scientific institutions, as well as business entities. Third, the article looks at the efforts of cities and local governments to organize themselves in transnational networks and to build alliances for knowledge sharing and formulating best practices. While local governments generally have a good position in the multi-level governance system to engage actors at other governmental levels and societal scales into a policy dialogue, the following sections discuss the connectivity of cities and their governments to other actors in global sustainability governance.

\section{Cities and Their Governments in Global Sustainability Governance}

The important role of cities in the global response to transboundary environmental problems has already been mentioned in the Brundtland report published in 1987 (World Commission on Environment and Development, 1987, Chapter 8). Shortly after, it was re-emphasized in Agenda 21 which was an outcome of the Earth Summit in Rio de Janeiro in 1992 (United Nations, 1992). With the adoption of the 2030 Agenda and the 17 SDGs in 2015, cities have once again been put in the spotlight of the global endeavor to foster sustainability. Yet, the question of how urban sustainability actions are embedded in complex interactions between public and private actors operating at different levels has not been studied in much detail.

\subsection{Vertical Integration and Involvement in International Conferences}

Cities and their governments are confronted with numerous sustainability challenges which require local strategies and policies for mitigating air pollution, advancing public transportation systems, improving waste and water management or providing access to basic health facilities for all citizens. Comparative studies on urban sustainability actions demonstrate that the capacities and autonomy of local authorities vary considerably from policy domain to policy domain and from country to country (e.g., Kern \& Mol, 2013; Ladner, Keuffer, \& Baldersheim, 2016). Swedish municipalities are described as actors with relatively strong resources and leeway to carry out sustainability measures in their jurisdictions (Kronsell \& Mukhtar-Landgren, 2018). In contrast, cities in India have a very weak position in the domestic public-administrative system and lack financial means to undertake sustainability projects (Beermann, Damodaran, Jörgensen, \& Schreurs, 2016).

Regardless of the varying capacity and autonomy across cities, legal frameworks at higher governmental levels play a decisive role in shaping local policy options for sustainability. To implement large-scale sustainability projects, cities rely on regional and national governments (Homsy \& Warner, 2015). In fact, most local governments have limited institutional capacities and financial resources for addressing sustainability (Stehle, Hickmann, Lederer, \& Höhne, 2020; Wang, Hawkins, Lebredo, \& Berman, 2012). In many cities of the global South where national governments face serious budgetary limitations, effective sustainability actions depend on external funding provided by international agencies or bilateral donors (Nagendra et al., 2018; Stehle, Höhne, Hickmann, \& Lederer, 2019). Moreover, urban sustainability initiatives are in many countries hampered by uncoordinated and partly overlapping responsibilities within local government (Cugurullo, 2018; Homsy, 2018) as well as by vested interests, especially in the energy, transportation, or land-use sectors (Elsässer, Hickmann, \& Stehle, 2018).

In recent years, cities have increasingly become involved in international conferences. In the global climate regime complex, cities have officially been recognized as 'governmental stakeholders' in 2010 after local governments put considerable effort into augmenting the position of cities in the international climate 
negotiations (Zeppel, 2013). In a similar vein, cities are involved in the High-Level Political Forum on Sustainable Development taking place annually under the auspices of the United Nations to track progress of the implementation of the SDGs (Beisheim, 2015; Dellas, Carius, Beisheim, Parnell, \& Messner, 2018). At these events, local governments bring in joint interests and showcase urban sustainability initiatives. In 2018, a number of cities started to emulate the national reporting process and submitted Voluntary Local Reviews to highlight their efforts to realize the 2030 Agenda in urban areas (Institute of Global Environmental Strategies, 2020).

While this development underlines the ambition of local governments to become global actors in global sustainability governance, scholars point out that such activities are primarily aimed at raising awareness and attracting funding for sustainability projects from higher governmental levels and private actors (Alberti \& Senese, 2020; Hickmann, 2017). Without the support of national and regional, as well as international funding, local authorities are largely constrained in their activities (Haarstad \& Wathne, 2019; Homsy \& Warner, 2015). Well-functioning vertical relations to actors at higher governmental levels and international agencies are hence crucial for propelling and maintaining urban sustainability initiatives.

\subsection{Horizontal Interactions}

Cities and their governments are in relative proximity to their population which enables them to bring together different stakeholders and balance different interests to formulate local sustainability solutions. According to different authors, this position is a key advantage of cities and local governments illustrating their large potential for contributing to the promotion of sustainability worldwide (McGranahan \& Satterthwaite, 2003; Satterthwaite, 1997). This idea has also been the cornerstone of Agenda 21 which stipulates that local governments should enter into a dialogue with their citizens, community organizations, and private companies, and adopt a Local Agenda 21 to guide the development of their areas towards a more sustainable future (United Nations, 1992, Chapter 28).

A number of cases are described in the literature that show how pioneering local authorities have been successful in forging connections between citizens, non-governmental organizations, and private corporations leading to innovative urban sustainability actions (e.g., Eckerberg, 2012; Selman, 1998). Key success factors identified in the literature include leadership combined with a well-equipped public administration, an active civil society, and a flourishing local green industry (Fitzgerald, 2010; Gilbert, Stevenson, Girardet, \& Stren, 2013; Smardon, 2008). In recent years, some local governments have created and become engaged in urban transition spaces where local stakeholders can experiment and develop sustainability solutions in their districts. In such co-creative processes, local authorities are expected to change their roles from traditional governors to facilitators, enablers, and connectors that build trust among local actors (Marvin, Bulkeley, Mai, McCormick, \& Palgan, 2018; Nevens, Frantzeskaki, Gorissen, \& Loorbach, 2013). This underscores the large potential of local governments to act as transmission belts between the 2030 Agenda and different societal stakeholders.

The entanglement of public and private actors in current governance instruments for promoting sustainability at the local level also bears the danger that private actors take advantage of their influential role as local job provider to lobby for their individual interests which can be detrimental to the provision of the common good. In particular, scholars have shown how private corporations resisted and even undermined local regulation of environmentally harmful practices (Campbell, 1996; Theodore, Peck, \& Brenner, 2011). Yet, other studies stress that public and private interests can be brought in line with each other to increase the common good and promote the overall objective of urban sustainability (Solano, Casado, \& Ureba, 2017; Van Berkel, Fujita, Hashimoto, \& Geng, 2009).

In such horizontal interactions, scientific actors can also play a crucial role for enhancing sustainability at the local level (Bansard, Hickmann, \& Kern, 2019). Universities and other scientific institutes provide evidence-based input for urban sustainability policymaking (Romero-Lankao et al., 2018). Scientists engage with local stakeholders in real-world laboratories aimed at reducing the carbon footprint of certain neighborhoods or corporations (Evans \& Karvonen, 2014). Researchers contribute to local capacity building and public awareness on sustainability issues and self-govern their behavior towards greater sustainability by limiting air travel, supporting green procurement, or purchasing environmentally-friendly goods (Chaudhury, Vervoort, Kristjanson, Ericksen, \& Ainslie, 2013). Such steps require that scholars change their self-conception of neutral experts and leave their comfort zones (van der Hel, 2018).

However, on a global scale, there are still only relatively few instances where local governments, civil society groups, private companies, and researchers effectively work together to foster urban sustainability. While there are some promising examples (mostly in highly industrialized countries), the broader potential of such collaborations still needs to be exploited (Guerra, Schmidt, \& Lourenço, 2019; Nevens et al., 2013). According to Paul Fenton and Sara Gustafsson (2017, p. 131): "Significant barriers to change at the intramunicipal level exist, including capacity and resources deficits, political or other interests, or the complexity of the change itself." The focus on cities in the 2030 Agenda could spur urban sustainability action, but structural barriers of cities and their past experiences with Local Agenda 21 need to be reflected and taken seriously when designing sustainability initiatives at the local level. 


\subsection{Transnational Networks and Alliances}

Transnational city networks and alliances have a long tradition and date back to the beginning of the 20th century. Their key characteristics are a voluntary membership, self-governing procedures, and direct implementation of common decisions. In the early 1990s, around the time of the Earth Summit in Rio de Janeiro, several new networks and alliances have been established with the general aim to enhance urban sustainability actions (Keiner \& Kim, 2007). Since then, their number has been steadily increasing with a strong focus on the policy domain of climate change (e.g., Bulkeley, 2010). These networks and alliances enable coordination between local authorities with similar interests and allow for inter-municipal dialogues, while they, at the same time, seek to pool their members' influence and highlight the presence of cities at the global stage (Gordon, 2013; Toly, 2008).

Transnational city networks and alliances fulfill different functions and entail varying mechanisms through which they seek to steer their members (Kern \& Bulkeley, 2009). In particular, they generate knowledge and provide information on environmental issues, support applications for sustainability project funding and establish stable cooperation channels, set benchmarks and offer certificates for eco-friendly behavior, and get involved in international environmental negotiations and policy discourses on sustainable development. By all these means, networks and alliances encourage learning processes and the exchange of experiences among their city members that deal with sustainability on the ground (Hakelberg, 2014).

Several scholars have emphasized the large opportunities of transnational city networks and alliances to engage in global sustainability governance arguing that they work as policy entrepreneurs and agenda-setters (Acuto \& Rayner, 2016; Gordon \& Johnson, 2017). In particular, these authors point out that such networks and alliances can to some extent overcome the constraints imposed by national decision-making and international bureaucracies, while not being bound to party interests or political timetables. At the same time, other authors have highlighted that transnational networks and alliances lack adequate funding and heavily rely on financial flows from national governments, international agencies, and private foundations to maintain their services and campaigns (Betsill \& Bulkeley, 2007; Hickmann, 2016; Kern \& Bulkeley, 2009). Such a dependence on other actors renders cities prone to capture by external interests and agendas (e.g., Gordon, 2018).

Furthermore, recent studies that assess the degree to which transnational networks and alliances of cities steer their members towards sustainability practices and new organizational structures have come to only modest results (Gordon, 2018; Hickmann, Fuhr, Höhne, Lederer, \& Stehle, 2017). Scholars particularly contend that although such networks and alliances offer significant support for many cities, their initiatives often lead to nothing because of constraining factors in the national political-economic system as well as the lack of commitment from mayors and local public officials (Stehle et al., 2020).

In a similar vein, authors have shown that the actual effects of such networks and alliances in terms of climate change mitigation are very limited which applies to networks and alliances located in the global South and in the global North (Bansard, Pattberg, \& Widerberg, 2017; Stehle et al., 2019). They are essentially not drivers for urban sustainability and low-carbon development, but work rather as catalyst for enhanced action in cities with certain prerequisites, while their general impact is rather low due to persistent budgetary and institutional capacity constraints.

\section{Conclusions}

This article has discussed the entanglement and interconnectedness of cities and their governments in multi-level governance dynamics for sustainability. While pioneering sustainability initiatives in urban areas underscore the large potential of local authorities to contribute to global sustainability, some studies convey an overtly optimistic tone regarding the impact of local sustainability initiatives on global developments. They tend to overestimate the agency of local governments and seem to neglect that cities are heavily contingent on support from public and private actors to carry out effective sustainability actions in urban areas.

In particular, the article looked at three dimensions of the embeddedness of local authorities in multi-level sustainability governance. First, cities and local governments rely on regional and national governments, as well as international funding agencies to launch and maintain large-scale urban sustainability initiatives. Second, local authorities face structural barriers when designing innovative urban sustainability actions that bring together different local stakeholders and have to expand their traditional governor role. Third, the wider impact of transnational city networks and alliances on local sustainability initiatives is rather low and opens the door for external influence. Such limitations for local authorities to conduct effective urban sustainability actions are often neglected in the literature.

To foster global sustainability and achieve the 17 SDGs, efforts by all political and societal actors are required; and to exploit the full potential of local governments, urban sustainability initiatives must go hand in hand with higher-level policies and programs, enhance ownership of local stakeholders, and be integrated in transnational networks and alliances. Due to their proximity to citizens, local authorities have an advantageous position in the multi-level governance system allowing them to act as transmission belts between the 2030 Agenda and the plethora of local stakeholders operating in the field of sustainable development. Yet, such a function requires steady support from other governmen- 
tal levels, stable funding streams, and continuous peerto-peer learning in networks and alliances.

The all-encompassing character of the 2030 Agenda constitutes a challenge and a chance for cities and their governments. On the one hand, it puts an additional burden on local governments to support the implementation of the SDGs in their jurisdictions, while on the other hand they open up new possibilities for collaboration with actors at other levels and scales under the umbrella of the vision to transform our world. A key lesson from this article is that when assessing the global endeavor to achieve the SDGs, it makes no sense to look at individual actors in isolation from others. Cities and their governments are certainly crucial for achieving the SDGs, but we have to better understand their embeddedness in the multi-level governance system.

A promising avenue for future research is to explore collaborations between cities and other actors for upscaling or diffusing urban sustainability initiatives (Fuhr et al., 2018; Hakelberg, 2014; Peng et al., 2019; van Doren, Driessen, Runhaar, \& Giezen, 2018). As cities and urban areas are very heterogeneous, we warrant further knowledge on the success conditions of urban sustainability initiatives and their evolving relationship to national governments, international organizations, intergovernmental agencies, transnational networks and alliances, as well as business entities, scientific institutions, and civil society groups. Open questions in this context include whether, to what extent, and how the collaborative governance approaches of pioneering local authorities within the sustainability domain can be transferred to other cities with their particular characteristics.

\section{Acknowledgments}

The study has been generously funded by the European Research Council (ERC) through an Advanced Grant for the research project "Global Governance through Goals? Assessing and Explaining the Steering Effects of the United Nations Sustainable Development Goals" (GLOBALGOALS; project number 788001). I would moreover like to thank Frank Biermann, Harald Fuhr, Chris Höhne, Agni Kalfagianni, Kristine Kern, Markus Lederer, James Patterson, Sandra Schwindenhammer, Fee Stehle, Marjanneke Vijge, Sabine Weiland and two anonymous reviewers for valuable comments on the general idea and various earlier versions of this article.

\section{Conflict of Interests}

The author declares no conflict of interests.

\section{References}

Acuto, M. (2013). Global cities, governance and diplomacy: The urban link. New York, NY: Routledge.

Acuto, M., \& Rayner, S. (2016). City networks: Breaking gridlocks or forging (new) lock-ins? International
Affairs, 92(5), 1147-1166.

Alberti, A., \& Senese, M. (2020). Developing capacities for inclusive and innovative urban governance. In S. Cheema (Ed.), Governance for urban services: Access, participation, accountability, and transparency (pp. 127-152). Singapore: Springer.

Amen, M., Toly, N. J., McCarney, P. L., \& Segbers, K. (Eds.). (2011). Cities and global governance: New sites for international relations. Farnham: Ashgate.

Bache, I., Bartle, I., \& Flinders, M. (2016). Multi-level governance. In C. Ansell \& J. Torfing (Eds.), Handbook on theories of governance (pp. 486-498). Cheltenham: Edward Elgar Publishing.

Bäckstrand, K., Kuyper, J. W., Linnér, B.-O., \& Lövbrand, E. (2017). Non-state actors in global climate governance: From Copenhagen to Paris and beyond. Environmental Politics, 26(4), 561-579.

Bansard, J., Hickmann, T., \& Kern, K. (2019). Pathways to urban sustainability: How science can contribute to sustainable development in cities. GAIA-Ecological Perspectives for Science and Society, 28(2), 112-118.

Bansard, J., Pattberg, P., \& Widerberg, O. (2017). Cities to the rescue? Assessing the performance of transnational municipal networks in global climate governance. International Environmental Agreements, 17(2), 229-246.

Barber, B. R. (2013). If mayors ruled the world: Dysfunctional nations, rising cities. New Haven, CT: Yale University Press.

Barber, B. R. (2017). Cool cities: Urban sovereignty and the fix for global warming. New Haven, CT: Yale University Press.

Beermann, J., Damodaran, A., Jörgensen, K., \& Schreurs, M. A. (2016). Climate action in Indian cities: An emerging new research area. Journal of Integrative Environmental Sciences, 13(1), 55-66.

Beisheim, M. (2015). Reviewing the post-2015 sustainable development goals and partnerships: A proposal for a multi-level review at the High-level Political Forum. Berlin: Stiftung Wissenschaft und Politik.

Betsill, M. (2001). Mitigating climate change in US Cities: Opportunities and obstacles. Local Environment, 6(4), 393-406.

Betsill, M., \& Bulkeley, H. (2007). Looking back and thinking ahead: A decade of cities and climate change research. Local Environment, 12(5), 447-456.

Brenner, N. (1998). Global cities, glocal states: Global city formation and state territorial restructuring in contemporary Europe. Review of International Political Economy, 5(1), 1-37.

Bulkeley, H. (2010). Cities and the governing of climate change. Annual Review of Environment and Resources, 35, 229-253.

Bulkeley, H., \& Betsill, M. (2005). Rethinking sustainable cities: Multilevel governance and the 'urban' politics of climate change. Environmental Politics, 14(1), 42-63.

Bulkeley, H., \& Betsill, M. (2013). Revisiting the urban pol- 
itics of climate change. Environmental Politics, 22(1), 136-154.

Campbell, S. (1996). Green cities, growing cities, just cities? Urban planning and the contradictions of sustainable development. Journal of the American Planning Association, 62(3), 296-312.

Chan, S., Asselt, H. v., Hale, T., Abbott, K. W., Beisheim, M., Hoffmann, M., ... Widerberg, O. (2015). Reinvigorating international climate policy: A comprehensive framework for effective nonstate action. Global Policy, 6(4), 466-473.

Chan, S., Boran, I., van Asselt, H., lacobuta, G., Niles, N., Rietig, K., . . . Wambugu, G. (2019). Promises and risks of nonstate action in climate and sustainability governance. Wiley Interdisciplinary Reviews: Climate Change, 10(3). https://doi.org/10.1002/wcc.572

Chaudhury, M., Vervoort, J., Kristjanson, P., Ericksen, P., \& Ainslie, A. (2013). Participatory scenarios as a tool to link science and policy on food security under climate change in East Africa. Regional Environmental Change, 13(2), 389-398.

Cugurullo, F. (2018). Exposing smart cities and eco-cities: Frankenstein urbanism and the sustainability challenges of the experimental city. Environment and Planning A: Economy and Space, 50(1), 73-92.

Curtis, S. (2014). The power of cities in international relations. New York, NY: Routledge.

Davidson, K., Coenen, L., \& Gleeson, B. (2019). A decade of C40: Research insights and agendas for city networks. Global Policy, 10(4), 697-708.

Dellas, E., Carius, A., Beisheim, M., Parnell, S., \& Messner, D. (2018). Local and regional governments in the follow-up and review of global sustainability agendas. Berlin and Brussels: adelphi/Cities Alliance.

Dorst, H., van der Jagt, A., Raven, R., \& Runhaar, H. (2019). Urban greening through nature-based solution: Key characteristics of an emerging concept. Sustainable Cities and Society, 49, 1-8.

Eckerberg, K. (2012). Local participation and learning in nature protection: A Swedish success story. In J. Meadowcroft, O. Langhelle, \& A. Ru (Eds.), Governance, democracy and sustainable development: Moving beyond the impasse (pp. 55-74). Cheltenham: Edward Elgar Publishing.

Elsässer, J., Hickmann, T., \& Stehle, F. (2018). The role of cities in South Africa's energy gridlock. Case Studies in the Environment, 2, 1-7.

Evans, J., \& Karvonen, A. (2014). 'Give me a laboratory and i will lower your carbon footprint!' Urban laboratories and the governance of low-carbon futures. International Journal of Urban and Regional Research, 38(2), 413-430.

Fenton, P., \& Gustafsson, S. (2017). Moving from highlevel words to local action: Governance for urban sustainability in municipalities. Current Opinion in Environmental Sustainability, 26, 129-133.

Fitzgerald, J. (2010). Emerald cities: Urban sustainability and economic development. Oxford: Oxford Univer- sity Press.

Fuhr, H., Hickmann, T., \& Kern, K. (2018). The role of cities in multi-level climate governance: Local climate policies and the $1.5^{\circ} \mathrm{C}$ target. Current Opinion in Environmental Sustainability, 30, 1-6.

Gilbert, R., Stevenson, D., Girardet, H., \& Stren, R. (2013). Making cities work: Role of local authorities in the urban environment. London: Earthscan.

Gordon, D. (2013). Between local innovation and global impact: Cities, networks, and the governance of climate change. Canadian Foreign Policy Journal, 19(3), 288-307.

Gordon, D. (2018). Global urban climate governance in three and a half parts: Experimentation, coordination, integration (and contestation). Wiley Interdisciplinary Reviews: Climate Change, 9(6), 1-15.

Gordon, D., \& Acuto, M. (2015). If cities are the solution, what are the problems? The promise and perils of urban climate leadership. In C. Johnson, N. Toly, \& $\mathrm{H}$. Schroeder (Eds.), The urban climate challenge (pp. 63-81). New York, NY: Routledge.

Gordon, D., \& Johnson, C. A. (2017). The orchestration of global urban climate governance: Conducting power in the post-Paris climate regime. Environmental Politics, 26(4), 694-714.

Guerra, J., Schmidt, L., \& Lourenço, L. B. (2019). From local Agenda 21 to a localized Agenda 2030: The Portuguese and Brazilian cases in perspective. Community Development, 50(3), 352-367.

Gupta, J. (2007). The multi-level governance challenge of climate change. Environmental Sciences, 4(3), 131-137.

Haarstad, H., \& Wathne, M. W. (2019). Are smart city projects catalyzing urban energy sustainability? Energy Policy, 129, 918-925.

Hakelberg, L. (2014). Governance by diffusion: Transnational municipal networks and the spread of local climate strategies in Europe. Global Environmental Politics, 14(1), 107-129.

Hansen, S. B., Ban, C., \& Huggins, L. (2003). Explaining the "brain drain" from older industrial cities: The Pittsburgh region. Economic Development Quarterly, 17(2), 132-147.

Hickmann, T. (2016). Rethinking authority in global climate governance: How transnational climate initiatives relate to the international climate regime. London: Routledge.

Hickmann, T. (2017). The reconfiguration of authority in global climate governance. International Studies Review, 19(3), 430-451.

Hickmann, T., Fuhr, H., Höhne, C., Lederer, M., \& Stehle, F. (2017). Carbon governance arrangements and the nation-state: The reconfiguration of public authority in developing countries. Public Administration and Development, 37(5), 331-343.

Hoffmann, M. (2011). Climate governance at the crossroads: Experimenting with a global response after Kyoto. Oxford: Oxford University Press. 
Homsy, G. C. (2018). Size, sustainability, and urban climate planning in a multilevel governance framework. In S. Hughes, E. K. Chu, \& S. G. Mason (Eds.), Climate change in cities: Innovations in multi-level governance (pp. 19-38). Cham: Springer.

Homsy, G. C., \& Warner, M. E. (2015). Cities and sustainability: Polycentric action and multilevel governance. Urban Affairs Review, 51(1), 46-73.

Hooghe, L., \& Marks, G. (2001). Multi-level governance and European integration. Lanham, MD: Rowman \& Littlefield Publishers.

Hooghe, L., \& Marks, G. (2003). Unraveling the central state, but how? Types of multi-level governance. American Political Science Review, 97(2), 233-243.

Institute of Global Environmental Strategies. (2020). Online voluntary local review (VLR) lab. IGES. Retrieved from https://www.iges.or.jp/en/projects/ vir

Keiner, M., \& Kim, A. (2007). Transnational city networks for sustainability. European Planning Studies, 15(10), 1369-1395.

Kern, K., \& Alber, G. (2008). Governing climate change in cities: Modes of urban climate governance in multilevel systems. In OECD (Ed.), Competitive cities and climate change: Proceedings of the OECD conference, held in Milan from October 9-10 (pp. 171-196). Paris: OECD Publishing.

Kern, K., \& Bulkeley, H. (2009). Cities, Europeanization and multi-level governance: Governing climate change through transnational municipal networks. Journal of Common Market Studies, 47(2), 309-332.

Kern, K., \& Mol, A. (2013). Cities and global climate governance: From passive implementers to active codecision-makers. In J. E. Stiglitz \& M. Kaldor (Eds.), The quest for security: Protection without protectionism and the challenge of global governance (pp. 288-305). New York, NY: Columbia University Press.

Kousky, C., \& Schneider, S. H. (2003). Global climate policy: Will cities lead the way? Climate Policy, 3(4), 359-372.

Kronsell, A., \& Mukhtar-Landgren, D. (2018). Experimental governance: The role of municipalities in urban living labs. European Planning Studies, 26(5), 988-1007.

Ladner, A., Keuffer, N., \& Baldersheim, H. (2016). Measuring local autonomy in 39 countries (1990-2014). Regional \& Federal Studies, 26(3), 321-357.

Marks, G. (1993). Structural policy and multilevel governance in the EC. In A. W. Cafruny \& G. G. Rosenthal (Eds.), The state of the European Community: The Maastricht debate and beyond (Vol. 2, pp. 391-411). Boulder, CO: Lynne Riener Publishers.

Marvin, S., Bulkeley, H., Mai, L., McCormick, K., \& Palgan, Y. V. (Eds.). (2018). Urban living labs: Experimenting with city futures. London: Routledge.

McGranahan, G., \& Satterthwaite, D. (2003). Urban centers: An assessment of sustainability. Annual Review of Environment and Resources, 28, 243-274.
Nagendra, H., Bai, X., Brondizio, E. S., \& Lwasa, S. (2018). The urban south and the predicament of global sustainability. Nature Sustainability, 1(7), 341-349.

Nevens, F., Frantzeskaki, N., Gorissen, L., \& Loorbach, D. (2013). Urban transition labs: Co-creating transformative action for sustainable cities. Journal of Cleaner Production, 50, 111-122.

Peng, Y., Wei, Y., \& Bai, X. (2019). Scaling urban sustainability experiments: Contextualization as an innovation. Journal of Cleaner Production, 227, 302-312.

Román, M. (2010). Governing from the middle: The C40 cities leadership group. Corporate Governance, 10(1), 73-84.

Romero-Lankao, P., Bulkeley, H., Pelling, M., Burch, S., Gordon, D., Gupta, J., . . . Simon, D. (2018). Urban transformative potential in a changing climate. Nature Climate Change, 8(9), 754-756.

Rosenzweig, C., Solecki, W., Hammer, S. A., \& Mehrotra, S. (2010). Cities lead the way in climate-change action. Nature, 467(7318), 909-911.

Sassen, S. (1994). Cities in a world economy. Thousand Oaks, CA: Pine Forge Press.

Satterthwaite, D. (1997). Sustainable cities or cities that contribute to sustainable development? Urban Studies, 34(10), 1667-1691.

Scott, A. J. (Ed.). (2001). Global city-regions: Trends, theory, policy. Oxford: Oxford University Press.

Selin, H., \& VanDeveer, S. D. (2012). Federalism, multilevel governance and climate change politics across the Atlantic. In P. V. Steinberg \& S. D. VanDeveer (Eds.), Comparative environmental politics: Theory, practice and prospects (pp. 341-368). Boston, MA: MIT Press.

Selman, P. (1998). Local Agenda 21: Substance or spin? Journal of Environmental Planning and Management, 41(5), 533-553.

Sengers, F., Berkhout, F., Wieczorek, A. J., \& Raven, R. (2016). Experimenting in the city: Unpacking notions of experimentation for sustainability. In J. Evans, A. Karvonen, \& R. Raven (Eds.), The experimental city (pp. 15-31). Abingdon: Routledge.

Shmelev, S. (2017). Multidimensional sustainability assessment for megacities. In S. Shmelev (Ed.), Green economy reader (pp. 205-236). Cham: Springer.

Simon, D. (Ed.). (2016). Rethinking sustainable cities: Accessible, green and fair. Bristol: Policy Press.

Smardon, R. C. (2008). A comparison of local Agenda 21 implementation in North American, European and Indian cities. Management of Environmental Quality: An International Journal, 19(1), 118-137.

Sodiq, A., Baloch, A. A. B., Khan, S. A., Sezer, N., Mahmoud, S., Jama, M., \& Abdelaal, A. (2019). Towards modern sustainable cities: Review of sustainability principles and trends. Journal of Cleaner Production, 227, 972-1001.

Solano, S. E., Casado, P. P., \& Ureba, S. F. (2017). Smart cities and sustainable development: A case study. In 
M. Peris-Ortiz, D. R. Bennett, \& D. Pérez-Bustamante Yábar (Eds.), Sustainable smart cities: Creating spaces for technological, social and business development (pp. 65-77). Cham: Springer.

Stehle, F., Hickmann, T., Lederer, M., \& Höhne, C. (2020). Urban climate politics in emerging economies: A multi-level governance perspective. Urbanisation. Advance online publication. https:// doi.org/10.1177/2455747120913185

Stehle, F., Höhne, C., Hickmann, T., \& Lederer, M. (2019). The effects of transnational municipal networks on urban climate politics in the global south. In J. van der Heijden, H. Bulkeley, \& C. Certomà (Eds.), Urban climate politics: Agency and empowerment (pp. 210-230). Cambridge: Cambridge University Press.

Theodore, N., Peck, J., \& Brenner, N. (2011). Neoliberal urbanism: Cities and the rule of markets. In G. Bridge \& S. Watson (Eds.), The new Blackwell companion to the city (pp. 15-25). Malden, MA: Wiley-Blackwell.

Toly, N. J. (2008). Transnational municipal networks in climate politics: From global governance to global politics. Globalizations, 5(3), 341-356.

UN Habitat. (2016). Urbanization and development: Emerging futures. Nairobi: UN Habitat.

UNDESA. (2019). World urbanization prospects: The 2018 revision. New York, NY: United Nations Department of Economics and Social Affairs.

United Nations. (1992). Agenda 21: Earth Summit: The United Nations program of action from Rio. New York, NY: United Nations.

United Nations. (2015). Transforming our world: The 2030 Agenda for sustainable development. New York,
NY: United Nations.

Van Berkel, R., Fujita, T., Hashimoto, S., \& Geng, Y. (2009). Industrial and urban symbiosis in Japan: Analysis of the eco-town program 1997-2006. Journal of Environmental Management, 90(3), 1544-1556.

van der Hel, S. (2018). Science for change: A survey on the normative and political dimensions of global sustainability research. Global Environmental Change, $52,248-258$.

van Doren, D., Driessen, P., Runhaar, H., \& Giezen, M. (2018). Scaling-up low-carbon urban initiatives: Towards a better understanding. Urban Studies, 55(1), 175-194.

Vardoulakis, S., \& Kinney, P. L. (2019). Grand challenges in sustainable cities and health. Frontiers in Sustainable Cities, 1, 1-5.

Wang, X., Hawkins, C. V., Lebredo, N., \& Berman, E. M. (2012). Capacity to sustain sustainability: A study of US cities. Public Administration Review, 72(6), 841-853.

Weibust, I., \& Meadowcroft, J. (Eds.). (2014). Multilevel environmental governance: Managing water and climate change in Europe and North America. Cheltenham: Edward Elgar Publishing.

World Commission on Environment and Development. (1987). Our common future. Oxford: Oxford University Press.

Zeppel, H. (2013). The ICLEI cities for climate protection programme: Local government networks in urban climate governance. In T. Cadman (Ed.), Climate change and global policy regimes: Towards institutional legitimacy (pp. 217-229). New York, NY: Palgrave Macmillan.

\section{About the Author}

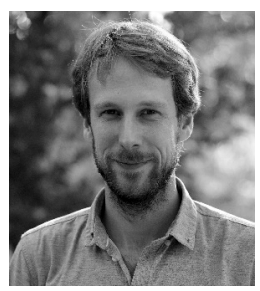

Thomas Hickmann is a Researcher with the Copernicus Institute of Sustainable Development at the Faculty of Geosciences, Utrecht University in the Netherlands. He is a core team member of the GlobalGoals project focusing on the steering effects of the United Nations Sustainable Development Goals and co-leads the Working Package 2.3 in the H2020 ENGAGE project on international constraints and enablers of decarbonization. 